\title{
MOTIVASI PEMBELAJARAN MAHASISWA PJKR UPGRIS VIA DARING/ONLINE SELAMA MASA COVID-19.
}

\author{
Ratihsartika31@gmail.com \\ Fakultas Pendidikan Ilmu Pengetahuan Sosial dan Keolahragaan . Universitas PGRI Semarang, \\ 50125, Indonesia. \\ * Ratih Sartika Sari. E-mail: ratihsartika31@gmail.com
}

Received: artikel dikirim; Revised: artikel revisi; Accepted: artikel diterima

\begin{abstract}
The background of this research is that after the many cases of Covid-19 in Indonesia, especially in Central Java, make every university learn online / online. The formulation of this problem is how the learning motivation of Upgris PJKR students via online / online during the covid-19 period. The purpose of this study was to determine the learning motivation of Upgris PJKR students via online / online during the covid-19 period. The research method used is descriptive quantitative research using a survey. The sample in this study were 89 students of PJKR Upgris. This research sampling technique using proportional random sampling. The data collection method used by researchers is a questionnaire.The results showed that students who were motivated to attend lectures online during the Covid-19 period were 56 respondents or $62.9 \%$, while those who had low motivation to attend lectures online during the Covid-19 period were 19. respondents or $21.4 \%$, while those who had high motivation in taking online lectures during the Covid-19 period were 14 respondents or $15.7 \%$. It was concluded that PJKR Upgris students were not motivated or enthusiastic in attending lectures and only attended online / online lectures because they followed the regulations imposed from the campus only. Based on data processing, it was found that there was moderate motivation in attending lectures online during the Covid-19 pandemic, namely 56 respondents or $62.9 \%$. Suggestions 1) To increase student motivation in taking online / online lectures during the Covid-19 period, this can be done by providing additional value for students who fulfill assignments given by lecturers. 2) To increase student discipline in taking online / online lectures, the lecturer can impose sanctions on students who do not take online / online lectures. 3) Lecturers can plan learning systems and delivery of more interesting materials such as making pictures and videos related to the lectures being conducted.
\end{abstract}

Keywords: Motivation, Learning, Online Learning, Learning Motivation.

\begin{abstract}
Abstrak
Latar belakang penelitian ini adalah Setelah banyaknya kasus covid-19 di Indonesia khususnya di Jawa Tengah, menjadikan setiap perguruan tinggi melakukan pembelajaran via daring/online. Rumusan masalah ini bagaimana motivasi pembelajaran mahasiswa PJKR Upgris via daring/online selama masa covid-19. Tujuan Penelitian ini untuk mengetahui motivasi pembelajaran mahasiswa PJKR Upgris via daring/online selama masa covid-19. Metode penelitian yang digunakan yaitu penelitian deskriptif kuantitatif dengan menggunakan survey. Sampel dalam penelitian ini adalah mahasiswa PJKR Upgris yang berjumlah 89 mahasiswa. Teknik sampling penelitian ini menggunakan proposional random sampling. Metode pengumpulan data yang digunakan oleh peneliti adalah angket/kuisioner. Hasil penelitian menunjukkan bahwa mahasiswa memiliki motivasi yang sedang dalam mengikuti perkuliahan secara daring/online selama masa Covid-19 yaitu sebanyak 56 responden atau $62,9 \%$, sedangkan yang memiliki motivasi rendah dalam mengikuti perkuliahan secara daring/online selama masa Covid-19 sebanyak 19 responden atau 21,4\%,
\end{abstract}


sementara yang memiliki motivasi tinggi dalam mengikuti perkuliahan secara daring/online selama masa Covid-19 sebanyak 14 responden atau 15,7 \%. Disimpulkan bahwa mahasiswa PJKR Upgris belum termotivasi atau tidak terlalu antusias dalam mengikuti perkuliahan dan hanya mengikuti perkuliahan daring/online karena mengikuti peraturan yang diberlakukan dari kampus saja. Berdasarkan pengolahan data didapatkan motivasi sedang dalam mengikuti perkuliahan secara daring/online selama masa pandemi covid-19 yaitu sebanyak 56 responden atau 62,9\%. Saran 1) Untuk meningkatkan motivasi mahasiswa dalam mengikuti perkuliahan melalui daring/online di masa Covid-19 ini dapat dilakukan dengan memberikan nilai tambahan bagi mahasiswa yang memenuhi tugas yang diberikan dosen. 2) Untuk meningkatkan kedisiplinan bagi mahasiswa dalam mengikuti perkuliahan melalui daring/online maka dosen dapat memberikan sanksi bagi mahasiswa yang tidak mengikuti perkuliahan secara daring/online. 3) Dosen dapat merencanakan sistem pembelajaran dan penyampaian materi yang lebih menarik seperti membuat picture maupun video yang berkaitan dengan perkuliahan yang dilakukan.

Kata kunci : Motivasi, Pembelajaran, Pembelajaran Daring, Motivasi Belajar.

\section{PENDAHULUAN}

Adanya pandemi Covid-19 di Indonesia saat ini telah merubah sistem pembelajaran dari pembelajaran tatap muka menjadi pembelajaran di rumah secara daring (online). Hal ini dilakukan sebagai upaya mencegah penularan virus corona tersebut. Pemerintah melalui Kementerian Pendidikan dan Kebudayaan menerapkan kebijakan belajar dan bekerja dari rumah sesuai dengan surat edaran Kementerian Pendidikan dan Kebudayaan (Kemendikbud) No. 4 tahun 2020 tentang pelaksanaan kebijakan pendidikan dalam masa darurat penyebaran Coronavirus Disesase (Covid-19) terkait proses belajar menyatakan bahwa belajar dari rumah melalui pembelajaran daring/jarak jauh dilaksankan untuk memberikan pembelajaran yang bermakna bagi mahasiswa. Pembelajaran online sampai saat ini masih dianggap sebagai terobosan atau paradigma baru dalam kegiatan belajar mengajar dimana dalam proses kegiatan belajar mengajar karena antara mahasiwa dan dosen tidak perlu hadir ruang kelas. Mereka hanya mengandalkan koneksi internet untuk melakukan proses kegiatan belajar dan proses tersebut dapat dilakukan dari tempat yang berjauhan. Dengan demikian pembelajaran online dapat dilakukan dari manapun mahasiswa dan dosen berada.

Seperti yang terjadi pada masa pandemi ini, wabah virus Covid-19 yang sedang melanda diberbagai belahan dunia termasuk Indonesia, dengan begitu Indonesia spontan membuat kebijakan seluruh aktivitas mulai dari bekerja dari rumah, ibadah dari rumah hingga belajarpun dari rumah. Sehingga pembelajaran daring/online diberlakukan di seluruh Perguruan Tinggi di Indonesia. Pembelajaran melalui daring/online dirasa sebagai alternatif pada saat pandemi ini karena tidak memerlukan tatap muka langsung antara dosen dan mahasiswa, hanya mengandalkan koneksi internet saja. 
Progam S1 Pendidikan Jasmani Kesehatan dan Rekreasi yang ada di Universitas PGRI Semarang juga menggunakan pembelajaran via daring/online dengan adanya pandemi ini. Perkuliahan daring/online dilakukan melalui via Email, WA ataupun dengan menggunakan alat interaksi online yang sudah disetujui antara mahasiswa dengan dosen masing-masing. Akan tetapi pada saat pembelajaran daring/online berlangsung ada beberapa mahasiswa yang tidak mengikuti pembelajaran daring karena terhalang oleh sinyal dan ada pula yang tidak mengikuti pembelajaran daring/online tanpa keterangan atau bolos. Perkuliahan yang dilakukan secara daring/online dapat menyebabkan berbagai macam pandangan terhadap motivasi mahasiswa. Ada mahasiswa yang merasa termotivasi dengan adanya perkuliahan daring/online tersebut namun banyak juga mahasiswa yang bahkan kurang termotivasi dengan perkuliahan melalui daring/online yang dilakukan.

Rendahnya motivasi belajar mahasiswa sering dianggap sebagai penyebab rendahnya kualitas lulusan sebuah perguruan tinggi. Pada kebanyakan perguruan tinggi, faktor ini bahkan menimbulkan persoalan dilematis, karena dengan rendahnya motivasi belajar, sebenarnya tidak mungkin mahasiswa dapat menguasai bahan pembelajaran dengan baik.

\section{METODE}

Penelitian ini merupakan penelitian deskriptif kuantitatif dengan metode survey yang dilakukan secara online. Pengumpulan data pada penelitian ini dengan menyebarkan kuisioner. Adapun hasil dari data yang berupa tanggapan mahasiswa terhadap pembelajaran melalui daring/online dijelaskan dalam bentuk tabel untuk memudahkan pemahaman penjelasan penelitian.

\section{Populasi dan Sampel}

\begin{tabular}{|l|l|c|l|c|}
\hline No & Semester & Populasi & \multicolumn{1}{|c|}{ Proporsional } & Sampel \\
\hline 1. & Semester 2 & 246 & $\frac{246}{770} \times 89=28,43$ & 28 \\
\hline 2. & Semester 4 & 256 & $\frac{256}{770} \times 89=29,58$ & 30 \\
\hline 3. & Semester 6 & 268 & $\frac{268}{770} \times 89=30,97$ & 31 \\
\hline \multicolumn{2}{|l|}{ Jumlah } & 770 & & 89 \\
\hline
\end{tabular}

Berdasarkan tabel diatas, ada tiga semester genap yang dijadikan penelitian yaitu semester 2, semester 4 dan semester 6 yang diambil secara acak. 


\section{Instrumen}

Penelitian menggunakan kuesioner yang dibuat via google form yang selanjutnya di bagikan kepada mahasiswa berupa link dengan total jumlah 27 pertanyaan. Kuisioner digunakan untuk mengetahui respon pembelajaran via daring mahasiswa selama pandemi Covid-19. Penulis juga menggunakan kuisioner sebagai instrumen untuk menganalisis data dan menjawab rumusan masalah yang dibahas pada penelitian ini.

\section{Teknik Pengumpulan Data}

Teknik pengumpulan data dalam penelitian ini yaitu penyebaran angket (kuisioner) secara online. Pada penelitian ini penulis menyebarkan kuisioner link tentang aktivitas fisik siswa selama pandemi Covid-19 dengan total 27 pertanyaan.

\section{Teknik Analisis Data}

Teknik analisis data yang digunakan adalah teknik analisis deskriptif, yaitu dengan mendeskriptifkan dan memaknai data dari masing-masing komponen. Data yang diproleh dari hasil pengumpulan data akan dianalisis dengan teknik diskriptif kuantitatif. Hasil perhitungan statistik deskriptif akan disajikan dalam bentuk tabel.

\section{HASIL DAN PEMBAHASAN}

Dalam penelitian ini jumlah responden laki-laki berjumlah 68 atau 76,4 \% dan perempuan berjumlah 21 atau 23,6\%. Dari total 89 responden terbagi dalam tiga semester, semester 2 berjumlah 28 responden atau 31,5\%, semester 4 berjumlah 30 responden atau 33,7 \% dan semester 6 berjumlah 31 responden atau $34,8 \%$. Berdasarkan penelitian yang dilakukan ditemukan hasil bahwa sebagian besar mahasiswa memiliki motivasi yang sedang dalam mengikuti perkuliahan secara daring/online selama masa pandemi Covid-19 yaitu sebanyak 56 responden atau 62,9\%. Sehingga dapat dikatakan bahwa motivasi mahasiswa PJKR Upgris untuk mengikuti perkuliahan secara daring/online belum termotivasi atau tidak terlalu antusian dalam mengikuti peraturan yang diberlakukan dari kampus. Hal ini mengindikasikan bahwa mahasiswa tidak begitu termotivasi dengan pembelajaran melalui daring/online yang dilakukan dalam perkuliahan di masa pandemi Covid-19 ini. Mahasiswa hanya melakukan perkuliahan secara daring/online karena kondisi dan pemberlakuan sistem pendidikan yang harus dilakukan secara daring/online dalam mengatasi penyebaran Covid-19 ini.

\section{KESIMPULAN}

Mahasiswa PJKR Upgris belum termotivasi atau tidak terlalu antusias dalam mengikuti perkuliahan dan hanya mengikuti perkuliahan daring/online karena mengikuti peraturan yang 
diberlakukan dari kampus saja. Berdasarkan pengolahan data didapatkan motivasi sedang dalam mengikuti perkuliahan secara daring/online selama masa pandemi covid-19 yaitu sebanyak 56 responden atau $62,9 \%$.

\section{DAFTAR PUSTAKA}

Achmad Rifa'I dan Chatarina T. Anni. 2009. Psikologi Pendidikan. Semarang: UPT UNNES PRESS.

Adijaya, N \& Santosa, L.P. 2018. "Persepsi Mahasiswa Dalam Pembelajaran Online".10 (2) 550.

Amaludin, A. (2012). Motivasi belajar siswa dalam mengikuti pembelajaran pendidikan jasmani melalui aktivitas permainan kecil Tahun 2012. Skripsi. Jurusan Pendidikan Jasmani Kesehatan dan Rekreasi. Fakultas Ilmu Keolahragaan. Universitas Negeri Semarang

Budi, I.S. (2013). Motivasi Siswa Dalam Mengikuti Kegiatan Ekstrakulikuler Bola Voli Di SMA Negeri Se-Kota PekalonganTahun 2013. Skripsi. Semarang: Fakultas Ilmu Keolahragaan Universitas Negeri Semarang.

Cahyani, A, Listiana, I.D. \& Larasati, S.P.D. (2020). "Motivasi Belajar Siswa SMA pada Pembelajaran Daring di Masa Pandemi Covid-19". Jurnal Pendidikan Islam. 01 (3) 123-140.

Darmalaksana, W, Hambali, R.Y.A, Masrur, A, Muhlas. 2020. Analisis Pembelajaran Online Masa WFH Pandemic Covid-19 sebagai Tantangan Pemimpin Digital Abad 21. UIN Sunan Gunung Djati Bandung, 2020.

Dewi, L. 2017. RANCANGAN PROGRAM PEMBELAJARAN DARING DI PERGURUAN TINGGI. Universitas Pendidikan Indonesia. 2 (16).

Dimyati dan Mudjiono. 1994. Belajar dan Pembelajaran. Jakarta: Depdikbud.

Djaali. 2008. Psikologi Pendidikan. Jakarta: PT. Bumi Aksara

Emda, A, 2017. “Kedudukan Motivasi Belajar Dalam Pembelajaran”. Lantanida Journal. (5) 93-196.

Fallows, D. (2004). The Internet and Daily Life. Pew Research Center's Internet \& American Life Project.

Fitriyani, Y, Fauzi, I, Sari, M.Z. (2020). "Motivasi Belajar Mahasiswa Pada Pembelajaran Daring Selama Pandemik Covid-19".Jurnal Kependidikan. 2 (6) 165-175.

Fortune, M. F., Spielman, M., \& Pangelinan, D. T. (2011). Students' Perceptions of Online or Faceto-Face Learning and Social Media in Hospitality, Recreation and Tourism. MERLOT Journal of Online Learning and Teaching, 7 (1), 1-16.

Hamzah B. Uno. (2009). Teori Motivasi dan Pengukurannya Analisis di Bidang Pendidikan. Jakarta: Bumi Aksara.

Harris, J \& Koehler, M. (2009). Teacher's Tecnological Pedagogical Content Knowledge and Learning Activity Types: Curriculum-Based Technology Integration Reframed. Journal of Research om Technology in Education, 41 (4), page 393- 416.

Kamil, Mustofa. (2007). Teori Andragogi. Kumpulan Jurnal Ilmu dan Aplikasi Pendidikan hlm. 287322. 
Noberto. (2015). "Motivasi Siswa-Siswi Terhadap Pelaksanaan Ekstrakurikuler Bola Voli di SMAN 1 Sengah Temila Kabupaten Landak". Jurnal Pendidikan dan Pembelajaran Khatulistiwa. 2 (4) $1-15$.

Ozuah, Phillip, O. (2005). First, There Was Pedagogy and Then Came Andragogy. Einstein J. Biol. Med, page 83-87.

Pangondian, R.A, Santoso, P.I, Nugroho, E. (2019). "Faktor - Faktor Yang Mempengaruhi Kesuksesan Pembelajaran Daring Dalam Revolusi Industri 4.0”.

Rahardja, U, Lutfiani, N, Handayani, I, Suryaman, F.M. (2019). "Motivasi Belajar Mahasiswa Terhadap Metode Pembelajaran Online iLearning + Pada Perguruan Tinggi". Jurnal Ilmiah Sisfotenika. 2 (9) 1-202.

Raharjo, T., J., \& Suminar, T. (2010). Penerapan Pedagogi dan Andragogi Pada Pembelajaran Pendidikan Kesetaraan Kelompok Belajar Paket A, B, dan C di Kota Semarang. Fakultas Ilmu Pendidikan Universitas Negeri Semarang

Rasyidin, Waini. (2014). Pedagogik Teoretis dan Praktis. Bandung: PT. Remaja Rosdakarya. 12.

Rasyidin, Waini. (2007). Pedagogik Teoritis. Kumpulan Jurnal Ilmu dan Aplikasi Pendidikan. 33-52.

Rusdiana, E. (2020) "Respon pada Pembelajaran Daring bagi Mahasiswa Mata Kuliah Pengantar Hukum Indonesia”. INTEGRALISTIK. 1 (31) 1-12.

Sardiman A.M. 2004. Interaksi dan Motivasi Belajar Mengajar. Jakarta : Rajawali Press.

Sari, P. (2017).“Memotivasi Belajar Dengan Menggunakan E-Learning”. 2 (6) 20-34.

Sugiyono. 2019. Metode Penelitian Kuantitatif, Kualitatif, dan R\&D. Bandung: Alfabeta

Sugiyono. 2019. Statistika Untuk Penelitian. Bandung: Alfabeta

Suharsimi Arikunto. 2006. Prosedur Penelitian Suatu Pendekatan Praktek. Jakarta : PT. Rineka Cipta.

Sur, W.A.A, Hasanah, M, Mustofa, M.R. (2020). "Analisis Motivasi Belajar Mahasiswa dengan Sistem Pembelajaran Daring Selama Masa Pandemi Covid-19”. Jurnal Equation. 2 (3) 40-52.

Syafei, M.M, Abduloh, Hidayat, T. (2019). SURVEY MOTIVASI SISWA DALAM PEMBELAJARAN SENAM KELAS IX SMP 2 KLARI. JUDIKA (JURNAL PENDIDIKAN UNSIKA). 1 (7) 86-98.

Pusdiklat Pegawai Kementerian Pendidikan dan Kebudayaan. "SURAT EDARAN MENDIKBUD NO 4 TAHUN 2020 TENTANG PELAKSANAAN KEBIJAKAN PENDIDIKAN DALAM MASA DARURAT PENYEBARAN CORONA VIRUS DISEASE (COVID- 19 )," 24 Maret 2020. https://pusdiklat.kemdikbud.go.id/surat- edaran-mendikbud-no-4-tahun-2020-tentangpelaksanaan-kebijakan-pendidikan-dalam-masa-darurat-penyebaran-corona-virus-disease-

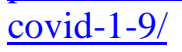

